\title{
Reasonable Accommodation for People with Disabilities in the Labour Market
}

\author{
Joseph Rankgale Modise \\ LLB (University of North West), LLM in Labour Law \& Social Security (North West University). \\ Sessional Lecturer, Graduate School of Business \& Government Leadership, \\ North West University, Mafikeng Campus, Republic of South Africa
}

\section{Marius Potgieter Olivier}

North West University, Mafikeng Campus, Faculty of Law, Republic of South Africa

\section{Ogutu Miruka}

PhD (Wits) Associate Professor of Management Sciences, Graduate School of Business \& Government Leadership, North West University, Mafikeng Campus, Republic of South Africa Email address: mirukaco@gmail.com

\section{Doi:10.5901/mjss.2014.v5n4p578}

\section{Abstract}

The article discusses the legal and constitutional framework of reasonable accommodation of people with disabilities in the labour market. The study aims to remedy the potential pitfalls faced by employers and employees who do not understand the principles of reasonable accommodation of people with disabilities in the workplace. Studies regarding the protection and accommodation of people with disabilities in the labour market in South Africa are few and far between. This study aims to contribute to this field motivated by the desire to enable more people with disabilities to access the labour market. This is a theoretical research article meant to advance and disseminate developments regarding reasonable accommodation of people with disabilities in the workplace. The study presents a legal analysis of the implications of reasonable accommodation of people with disabilities in the workplace. The analysis presented here is meant to help employers avoid unfair labour practices that could result in heavy penalties as well as potentially stifling the career progress and productivity of affected employees. The study helps to fill some gaps in the literature locally.

\section{Introduction}

Disability rights are recognised in the Constitution of South Africa. The adoption of the 1993 Constitution ${ }^{1}$ and the 1996 Constitution ${ }^{2}$ represents a major change to the face of the legal system in this country. The right to equality was given constitutional recognition for the first time when the 1993 Constitution was adopted and it also meant equal treatment for people with disabilities. People with disabilities are unfairly discriminated against on a daily basis in employment places as a result of widespread ignorance, fear and stereotypes. It is because of these negative perceptions that they experience high unemployment levels and often remain in low status jobs and earn lower salaries generally.

It is a fact that disability differs from one person to another and there are those people who can still perform their duties irrespective of their disabilities. This category of people must be reasonably accommodated at the workplace. South Africa is one of the few countries that have constitutionally entrenched the rights of people with disabilities while at the same time passing legislation that ensures that people with disabilities have rights and protection at the workplace. ${ }^{3}$

This article will examine the constitutional provisions, statutory provisions and policies relating to the reasonable accommodation of people with disabilities in the workplace. Another aim of this article is to highlight the constitutional dispensation responsive to the call for equal treatment and accommodation of people with disabilities in the workplace.

This paper focuses on domestic laws and government policies providing for reasonable accommodation of people with disabilities in the labour market. It will also reflect on the need for law reform as appropriate. The Constitution of the

\footnotetext{
1200 of 1993. Hereafter referred to as the Interim Constitution of the Republic of South Africa.

${ }^{2}$ Constitution of the Republic of South Africa, 1996.

${ }^{3}$ Dupper 0 et al Essential Employment Discrimination Law (2004) 154.
} 
Republic of South Africa is the supreme law of the country. Section 172(1) provides that when deciding a Constitutional matter within its power, a court must declare that any law or conduct that is inconsistent with the Constitution is invalid to the extent of its inconsistency and may make any order that is just and equitable, including an order limiting the retrospective effect of the declaration of invalidity. ${ }^{4}$

The 1996 Constitution endorses the idea that disability discrimination should not be tolerated in a democratic South Africa. The fundamental rights to equality and to human dignity are central to the protection of people with disabilities. The South African courts have consistently held, also in the area of employment, that there is a close correlation between the right to equality and the protection of a person's dignity, and in Walters $v$ Transitional local council of Port Elizabeth ${ }^{5}$, the court held that at the heart of the prohibition of unfair discrimination is the recognition that under the Constitution all human beings, regardless of position in society, must be accorded equal dignity.

\section{Research Design}

This is a theoretical research article that is largely informed by readily available data concerning the accommodation of people with disabilities in the South African workplace. Our point of departure is the advocacy by the Constitution of the Republic of South Africa which indisputably prohibits any form of discrimination based on listed grounds ${ }^{6}$ or analogous grounds. The 1996 Constitution endorses the idea that disability discrimination should not be tolerated in a democratic South Africa. The fundamental rights to equality and to human dignity are central to the protection of people with disabilities. In the case of Harksen $v$ Lane $^{7}$, the Constitutional Court stated the following "What the specified grounds have in common is that they have been used or misused in the past to categorise, marginalize and often oppress persons who have had or who have been associated with, these attributes or characteristics. These grounds have the potential to demean persons in their inherent humanity and dignity."

In the case mentioned above, the court listed various factors that must be considered in making the determination of unfairness or otherwise. These factors are: the position of the complainants in society; the nature of the provision or power; the purpose and the extent to which the discrimination has affected the rights of the complainants; and whether it has led to an impairment of their fundamental dignity. The determining factor in deciding whether discrimination is unfair is its impact on the people affected in particular whether it has impacted on a person's dignity. In the case of Liberty Life Association $v \mathrm{George}^{8}$, the court acknowledged that, because of South Africa's past, a need exists to address previous discrimination.

Section 9(2) of the South African Constitution provides that "Equality includes the full and equal enjoyment of all rights and freedoms. According to this section, the achievement of equality, protection and advancement of persons or categories of persons, disadvantaged by unfair discrimination, necessitates implementation of relevant laws and progressive measurers. These measures include Affirmative Action programmes.

This type of programme can be seen as an exception to the right to equality or as part of the right to equality. The former view sees Affirmative Action as 'reverse discrimination', a practice of favouring those discriminated against in the past and the latter view sees it as a means to an end of a more equal society. This view treats equality as a long term goal to be achieved through measures and programmes aimed at advancing previously designated groups.

Affirmative Action programs must therefore be seen not as a derogative from, but a substantive and composite part of the right to equality. Differentiation aimed at protecting or advancing persons disadvantaged by unfair discrimination is therefore warranted provided the measures are shown to conform to the internal test. ${ }^{9} \mathrm{~A}$ measure that favours relatively disadvantaged groups at the expense of those who are relatively well off is not unfairly discriminatory because the consequences of a such a measure are, in the long run, a more equal society. This means that the mere fact that a measure is intended at advancing and promoting those who were previously unfairly discriminated is sufficient.

In order to elucidate the need for reasonable accommodation of people with disabilities in the labour market, it is of paramount significance to rely on case which will provide a better understanding and interpretation. The South African courts have consistently held, also in the area of employment, that there is close correlation between the right to equality

\footnotetext{
${ }^{4}$ Constitution of the Republic of South Africa, 1996.

${ }^{5}$ Walters v Transitional local council of Port Elizabeth2001 SA 98 (LC).

${ }^{6}$ Section 9(3), Constitution of South Africa, 1996.

${ }^{7}$ Harksen v Lane 1998 (1) SA 300 (CC).

${ }^{8}$ Liberty Life Association v George 1996 BLLR 985 (IC).

9 De Waal J and Currie I "The Bill of Rights, Handbook" (2005) 264.
} 
and the protection of a person's dignity, and in Walters $v$ Transitional local council of Port Elizabeth ${ }^{10}$, the court held that at the heart of the prohibition of unfair discrimination is the recognition that under the Constitution all human beings, regardless of position in society, must be accorded equal dignity.

In the case of Brink $v$ Kitshof ${ }^{11}$, the Constitutional Court argued that the primary purpose of the equality clause in the 1993 Constitution that preceded the final constitution was to prohibit patterns of discrimination and their results. The recognition of the right to equality in the 1996 Constitution is one of the most important human rights principles. This section provides that "everyone is equal before the law and has the right to equal protection and benefit of the law. ${ }^{12}$ In cases of dismissals necessitated by incapacity or disability, employer is obliged to consider number of factors, among others, the nature of the disability, the cause of disability, prospects of recovery and alternative placement. Failure to accommodate people with disabilities in the workplace amounts to automatically unfair dismissals.

In Lagadien v University of Cape Town ${ }^{13}$, an employee was appointed on contract as acting co-ordinator of the respondent's disability unit. It had been agreed that her responsibilities would be re-negotiated if a new head of the unit were appointed prior to the termination of her contract. The post was advertised and four candidates were interviewed. A black woman with disability from Zimbabwe was appointed. However due to the difficulties she encountered with her work permit she could not accept the offer.

The Employment Equity Act is of great importance in ensuring that there are equal opportunities for those who are falling within the umbrella of designated groups. Designated groups are blacks, people with disabilities, women, Indians and Coloureds. In Hoffman $v$ South African Airways ${ }^{14}$, the airline policy was that people who are HIV-positive could not be employed as cabin attendants. An applicant who was HIV-positive applied for a post as a cabin attendant and he was not appointed as a result of his status. It was argued that the policy amounted to unfair discrimination on the listed ground of disability.

The Constitution of the Republic of South Africa is the supreme law of the country. Section 172(1) ${ }^{15}$, provides that when deciding a Constitutional matter within its power, a court must declare that any law or conduct that is inconsistent with the Constitution is invalid to the extent of its inconsistency and may make any order that is just and equitable, including an order limiting the retrospective effect of the declaration of invalidity. In all the above cases, it is apparent that the court has adopted a zero tolerance on the issue of discrimination based on number of grounds including disability discrimination, and emphasized the pursuit to equal treatment.

\section{Results}

This section discusses the various policies and legislation that deal with reasonable accommodation of people with disability in the labour market as well as the implementation challenges. It further goes on to look into the relevant cases which the courts have pronounced its findings on, and whether or not there are lessons to be learnt. In July 1994, a ministerial legal task team was appointed to draft a new Labour Relations Act. The task team was instructed to draft a bill that would bring our legislation in line with various International Labour Organisation Conventions ${ }^{16}$. The first legislative response to the constitutional challenge of protecting all persons against unfair discrimination at the workplaces, including people with disabilities was expressed in the Labour Relations Act 66 of 1995, which in terms of schedule 7 item 2(1) (a) before it was repealed, and replaced by Chapter II of the Employment Equity Act 55 of 1998, prohibited discrimination based on various grounds including disability. ${ }^{17}$

\subsection{Integrated National Disability Strategy of 1997}

The Integrated National Disability Strategy was drafted and came into effect in 1997 after lengthy discussions with various stakeholders. This policy represents the government's approach to the development and integration of people with disabilities and to the promotion and protection of their rights. The Integrated National Disability Strategy provides a

\footnotetext{
10 Walters v Transitional local council of Port Elizabeth2001 SA 98 (LC).

11 Brink v Kitshof 19964 SA 197(CC).

12 section 9(1) Constitution of South Africa, 1996.

13 Lagadien v University of Cape Town 20011 SA 76 (LAC) .

14 Hoffman v SAA 200221 SA 2357 (IC).

15 Constitution of the Republic of South Africa, 1996.

${ }^{16}$ Dupper $O$ et al Essential Employment Discrimination law (2004 )21.

17 Labour Relations Act 66 of 1995.
} 
blueprint for the integration and inclusion of disability into every aspect of governance. Another important feature of this policy is that it articulates a paradigm shift from dealing with disability related issues as solely health and welfare issues to a rights-based integrated approach. ${ }^{18}$

The objectives of the Integrated National Disability Strategy includes: the facilitation of the integration of disability issues into developmental strategies, planning and programs; and the development of an integrated management system for the conciliation of disabilities planning, implementation and monitoring in the various line functions at all spheres of government. This policy articulates the point that people with disabilities should not be seen as objects of pity but rather as capable individuals who are and can contribute immensely to the development of the society. It also underscores the importance of transformation of attitudes, perceptions and behaviour towards people with disabilities. This is perhaps one of the greater challenges to overcome as people in general have an ingrained mindset as to what people with disabilities can do. ${ }^{19}$ The policy is, however, silent on how people with disabilities should be accommodated in the labour market.

\subsection{Labour Relations Act 66 of 1995}

The Labour Relations Act introduced an important change in the area of the employment practice. Important protection was provided for employees and job seekers against unfair discrimination on the basis of their disability particularly on the area of dismissal. The Labour Relations Act confirmed the constitutional right to equality. The Labour Relations Act prohibits discrimination based on various grounds including disability and regards such dismissal as automatically unfair.

The Labour Relations Act provides that a dismissal is automatically unfair ${ }^{20}$ if the employer in dismissing the employees unfairly discriminated against an employee, directly or indirectly on any arbitrary grounds, which includes among others disability. A dismissal may be fair if the reason for the dismissal is based on the inherent requirements ${ }^{21}$ of the particular job. In the case of dismissal, it is incumbent on the employer to prove that it is based on inherent requirements of the job.

An employer must always consider alternative options before dismissing employees. The employer is only allowed to consider dismissing an employee basically if dismissal is the last resort. The Labour Relations Act recognises the right of an employee not to be unfairly dismissed. The general procedure is that in cases of dismissals an employer is expected to prove that the dismissal was for a fair reason relating to any of the categories listed in section 188 of the Labour Relation Act and in compliance with a fair procedure. ${ }^{22}$ Two of these categories will be discussed below.

\subsection{Dismissal for Incapacity}

In the case of incapacity in the form of poor work performance, dismissal on the basis of poor work performance contemplates a dismissal of an employee who cannot meet the required performance as opposed to an employee who would not or could not be bothered to meet the standards. In the case of Mambula v AECI Explosives Ltd ${ }^{23}$, it was stated as a rule that the employer is permitted to dismiss an employee who is frequently absent due to illness and that this may be justified on the basis of operational requirements.

However, the employer is obliged to consult with employee and consider alternatives prior to dismissal. In Elvey International (pty) Ltd ${ }^{24}$, an employee was temporarily incapable of performing his duties due to psychological disorder caused by abuse of prescribed medication. He was then unfairly dismissed for operational reasons in the absence of employer consulting and counselling employee and giving him an opportunity to improve. The employer is generally obliged to assess the source of the problem, attempt to address it and investigate the existence of alternative measurers prior dismissing the employee.

This principle was reinforced in Burger v Governing Body of Newcastle Senior primary School25, an employee was

\footnotetext{
${ }^{18}$ McClain C V "Governance and Legislation in South Africa: A contemporary overview" issue no12, January-March 2002,www. Disability World.Org, 23 March 20042.

19 White Paper on Integrated National Disability Strategy 5 (November 1997).

20 Section 187(1) (f) of Labour Relations Act 66 of 1995

21 Supra, section 187 (2) $f$.

22 There are three categories which are listed in terms of section 188 of Labour Relations Act. These categories are Dismissal for Misconduct, Dismissal for Incapacity and Dismissal for Operational Requirements

${ }^{23}$ Mambula v AECI Explosives Ltd 19955 SA 62 (IC).

${ }^{24}$ Elvey International (Pty) Ltd 19955 SA 108 (IC).

${ }^{25}$ Burger v Governing Body of Newcastle Senior Primary 20052 BALR 175 (CCMA).
} 
dismissed for incapacity after she indicated that she required seven weeks unpaid leave to undergo an operation. The management had neither investigated the extent of the employee's incapacity nor did they give her an opportunity to state her case, subsequently she was dismissed. Dismissal was found to be unfair. In National Education Health \& Allied Workers Union obo Lucas v Department of Health: Western Cape ${ }^{26}$, the arbitrator found that in the cause of determining whether or not a dismissal based on incapacity was fair, regard should be paid to whether or not an employee is a person with disability as defined in the Employment Equity Act.

It is a fact that prior dismissal must comply with the fair procedure, including consulting with an employee with a hope of considering alternatives or temporary employee in case an employee will be absent for a long period. However, an employer cannot wait for an unreasonable period without prospects of recovery on the side of an employee, in this situation dismissal is the solution. In Henn v Eskom ${ }^{27}$, it was stated that employee's frequent and lengthy absence due to ill-health may justify termination at point where employer can no longer be expected to tolerate such absences. Evidence is required from employer to show that such point has been reached, and in Nehawu v SA Institute for Medical Research ${ }^{28}$, it was stated that a sympathetic approach is required from an employer. The Employer consulted thrice with an employee and waited for five years before dismissing an employee.

\subsection{Dismissal for Operational Requirements}

Operational requirements are defined in terms of Labour Relations Act, section 213 as "requirements based on the economic, technological, structural or similar needs of an employer". The Labour Relations Act 66 of 1995 also recognises the possibility of dismissal based on the employer's operational requirements. In terms of both sections 189 and $189 \mathrm{~A}^{29}$, the employer has to consult with a representative body of the workers, and the purpose of consultation among others is to minimise the numbers of persons who will be dismissed and also to reach consensus on issues such as measurers to avoid dismissal.

In cases of dismissal based on operational requirements, the employer is expected to prove that the dismissal was indeed based on the needs of the employer. Failure to prove the dismissal will be deemed to be unfair. In BMD Knitting Mills (Pty) Ltd $v$ Sactwu ${ }^{30}$ it was stated that in cases of dismissal based on operational retrenchment, the court would have to examine whether the decision to retrench was reasonable, having regard to employer's needs, and in SACWU \& others $v$ Afrox $\mathrm{Ltd}^{31}$, that in order for an employer to succeed in dismissal of operational requirements, he must prove that the reason for the dismissal was 'operational reasons' as defined.

In Numsa v Atlantis Diesel Engines Ltd 32 it was stated "fairness in this context goes further than a bona fide and commercial justification for the decision to retrench. It is concerned, first and foremost, with the question whether termination of employment is the only reasonable option in the circumstance. It has become trite for the courts to state that termination of employment for disciplinary and performance should always be a measure of last resort. This means that an employer must fairly prove that the dismissal was executed in good faith.

\subsection{The Employment Equity Act 55 of 1998}

The purpose of the Employment Equity Act is to achieve equity at the workplace by Promoting equal opportunities and fair treatment in employment through the elimination of unfair discrimination, and implementing Affirmative Action measurers to redress the disadvantage in employment experienced by the designated groups, in order to ensure their equitable representation in all occupational categories and levels in the workplace. ${ }^{33}$ People with disabilities are amongst those who are identified as beneficiaries of Affirmative Action programmes. ${ }^{34}$ The Employment Equity Act explicitly provides that unfair discrimination in the workplace based purely on the ground of disability is prohibited.

\footnotetext{
${ }^{26}$ Nehawu obo Lucas v Department of Health: Western Cape 200425 ILJ 2091 (BCA).

27 Henn v Eskom 19966 SA 747 (IC).

28 Nehawu v SA Institute for Medical Research 19972 SA 146 (IC).

29 Labour Relations Act 66 of 1995.

30 BDM Knitting Mills (Pty) Ltd v Sactwu 20017 BLLR SA 705 (LAC).

${ }^{31}$ SACTWU \& Others v Afrox Ltd 199910 BLLR SA 1005 LAC

32 Numsa v Atlantis Diesel Engines 1993 ILJ 642 (LAC).

${ }^{33}$ Isaak W "The prohibition of unfair discrimination in the workplace", published under www.equality.org.Za/Legal/Article, 23 March 2004

34 Dupper 0 et al Essential Employment Discrimination Law ( 2004 ) 159.
} 
In Hoffman $v$ South African Airways ${ }^{35}$, the airline policy was that people who are HIV-positive could not be employed as cabin attendants. An applicant who was HIV-positive applied for a post as a cabin attendant and he was not appointed as a result of his status. It was argued that the policy amounted to unfair discrimination on the listed ground of disability. The Constitutional Court avoided this argument, preferring to deal with HIV-status as an analogous ground. The determining factor when deciding whether the discrimination is unfair is its impact on the affected people. For people to be denied employment because of their HIV-positive status without regard to their ability to perform the duties of the position from which they have been excluded is a violation of their right to equality and human dignity.

Section 5 of the Employment Equity Act ${ }^{36}$ encourages employers to take steps in promoting equal opportunities in the workplace by eliminating unfair discrimination in any employment policy or practice. The Employment Equity Act is one of the most advanced legislative measurer in the field of equity and disability. The Act prohibits unfair discrimination in any employment policy or practice against people with disabilities. This Act goes further to call for implementation of affirmative action measures in favour of the designated groups.

This section obliges employers to eliminate all employment barriers or difficulties, which prevent designated groups, including people with disabilities from accessing employment. The employer is required to identify employment barriers, which are affecting people from the designated groups from accessing employment. For example, employment barriers in the area of recruiting employees with disability would occur when an employer fails to draft advertisements in such a way as to accommodate them.

It is submitted that the term employment barriers includes any criterion used in the context of an employment policy or practice, or any aspect of the physical or psychological working environment, which presents an unfair or unreasonable obstacle to the employment or promotion of black people, women or people with disability. The employers should consult with the employees who are affected by employment barriers in order to jointly identify them and develop a strategy of preventing them. Failure to prevent them on the part of the employer amounts to unfair discrimination.

According to section 15(1) of the Employment Equity Act ${ }^{37}$, affirmative action measures are "measures designed to ensure that suitably qualified people from designated groups have equal employment opportunities and are equitably represented in all occupational categories and levels in the workplace of a designated employer. A designated employer refers to an employer who employs 50 or more employees or to employers with less than 50 employees but who have more than a certain annual turnover depending on the economic sector they operate in. In the case of Public Servants Association of South Africa v Minister of Justice ${ }^{38}$, the court stated that the words 'designed' and 'achieve' denote a causal connection between the designed measurers and the objectives. The question is whether all people from designated groups are entitled to benefit under an Affirmative Action programme just because they were previously discriminated against. However, in order to stand a good of chance of benefiting, two requirements must be met which are that the employee must fall within the category of designated groups, and the employee must be suitably qualified.

This basically means that it is not enough if an employee or applicant falls within the category of the designated groups. He or she must be suitably qualified in order to stand a better chance of benefiting from Affirmative Action. Suitably qualified can be interpreted to mean that an employee is required among others things to be skilful, capable and knowledgeable or to possess necessary qualifications in order to be appointed.

In Lagadien v University of Cape Town ${ }^{39}$, an employee was appointed on contract as acting co-ordinator of the respondent's disability unit. It had been agreed that her responsibilities would be re-negotiated if a new head of the unit were appointed prior to the termination of her contract. The post was advertised and four candidates were interviewed. A black woman with disability from Zimbabwe was appointed. However due to the difficulties she encountered with her work permit she could not accept the offer. The post was re-advertised and the applicant applied again and she was not even interviewed.

The applicant contended that she was unfairly discriminated against on the basis of race or gender, but finally contended that the discrimination against her was based on lack of academic and tertiary qualifications. The respondent denied that the sole reason why the successful candidates had been preferred was the fact that they possessed tertiary qualifications. The court held that an allegation of discrimination raises a presumption of unfairness, which the respondent is obliged to rebut.

The respective advertisement for the post had not indicated that possession of tertiary qualifications was an

\footnotetext{
${ }^{35}$ Hoffman v South African Airways 2001 (1) SA 1 (CC).

3655 of 1998.

${ }^{37}$ supra.

${ }^{38}$ Public Servants Association of South Africa v Minister of Justice 19973 SA 925 (T).

${ }^{39}$ Lagadien v University of Cape Town 20011 SA 76 (LAC).
} 
inherent requirement of the position. On the contrary, the immutable requirements were "proven skills, experience and knowledge" in specified areas. The applicant was judged weaker than the successful candidates in one critical area, namely, assisting students with disabilities to cope with their lecture material. There was no doubt that the possession of academic qualifications would enhance the incumbent's ability to perform this function. There was accordingly no basis for concluding that the respondent had been arbitrary or capricious in attaching some weight to that factor when evaluating the applicants. The application was dismissed with costs.

The prohibition in section 20(5) of the Employment Equity Act against unfair discrimination solely on the ground of relevant experience relates only to the determination to be made in section 20(4) concerning whether a person is "suitably qualified" for the purpose of an employment equity plan. According to section 9(2) of the Constitution of South Africa, the beneficiaries of Affirmative Action may be persons or categories of persons disadvantaged by unfair discrimination. The Employment Equity Act obliges employers to implement measures such as Affirmative Action in favour of people with disabilities and this includes "making a reasonable accommodation" for the people from the designated groups to ensure that they enjoy equal opportunities. According to this section an employee must be capable or skilful in order to perform his or her duties.

There is nothing which prevents an employer in a situation where there are two applicants, one is able and skilful and another has a disability and is under-skilled, to appoint the capable applicant, and appoint the other as an intern with the idea of capacitating that person. There is no automatic qualification as a beneficiary of affirmative action. Those who allege that they have been discriminated against as a result of misuse of affirmative action programmes can seek recourse from our courts. It will be incumbent on the employer to prove that the appointment of the successful candidate was fair.

In the event that the employer has advertised vacancies and there are no suitable candidates from the designated groups and he also has no affirmative action plan, able-bodied employees must be employed. This was the position in the case of Coetzer and another v Minister of Safety and Security ${ }^{40}$ The white applicants were not appointed due to affirmative action. The applicants approached the Labour Court, as the employer did not have an affirmative action plan and also no suitable applicants from the designated groups applied for those vacancies. The court held that failure to appoint them was discriminatory.

In the early case of George V Liberty Life ${ }^{41}$, the applicant claimed that the choice of an affirmative action candidate over him amounted to an unfair labour practice. Mr. George, a white male was an internal candidate for the position. The court recognises that the unfair labour practice concept had on occasion been interpreted as prohibiting discrimination on arbitrary grounds. The court referred to this as a negative discrimination; however, the court acknowledged that it had never before considered whether positive discrimination was a legitimate exception to the right not to be unfairly discriminated against.

In order to answer this question, the court had to take the values of the broader community into consideration, most importantly the rights enshrined in the Constitution. The court accepted the necessity of affirmative action measure in order to assist those who have been historically disadvantaged, even though it amounted to a form of discrimination. Section 19 of the Employment Equity Act requires designated employers to conduct an analysis of their employment policies, practices and procedures and to compile a workforce profile. This analysis serves the purpose of identifying employment barriers in order to eliminate those barriers or obstacles. In respect of the applicable employment policies and practices, the analysis should identify which criteria were used; whether they potentially discriminate against persons of colour, women, or people with disabilities; and if so whether they are justified in terms of the actual requirements of the job. ${ }^{42}$

The Employment Equity Act is indeed welcomed by people with disabilities as progressive on the basis that it attempts to address the disadvantages faced by people with disability in the workplace. This Act does not prohibit failure to reasonably accommodate people with disabilities as a form of discrimination; it views it as a positive measure that must be included by employers to attain equal opportunities. ${ }^{43}$ Employers are obliged to reasonably accommodate the needs of people with disabilities. The accommodation might vary from one person to another. If an employer fails to accommodate the needs of people with disabilities or raises an excuse that accommodation is very expensive, then measures to remedy the situation must be put in place.

Possible factors that can be taken into account to determine whether a specific accommodation can be expected

\footnotetext{
${ }^{40}$ Coetzer \& Another v Min of Safety and Security 20033 SA 368 LC

${ }^{41}$ George v Liberty Life 1996 BLLR 985 (IC).

42 Du Toit et al Labour Relation Law- A Comprehensive Guide 493 (2003) 493.

43 Truter L, Disability Discrimination, Unpublished Doctoral Thesis University of Johannesburg 80.
} 
to be made include financial costs involved, the size of the employer, possible safety risks and the benefit acquired by the employee. ${ }^{44}$ The Employment Equity Act has been of great assistance to people with disabilities, as it promotes their rights at the workplace and prohibits discrimination of any nature. It also provides for equal opportunities and lastly it obliges employers to design measurer to accommodate the needs of people with disabilities.

The Employment Equity Act has managed thus far to promote equal employment opportunities and to eliminate employment barriers, which prevented designated groups including people with disabilities from accessing employment. In as mush as it accommodates designated groups, the shortfall is that it applies to employees defined in terms of section 1 of this Act and excludes certain categories of workers, for example independent contactors. The Promotion of Equality and Prevention of Unfair Discrimination Act was introduced in order to include those who are excluded in terms of section 1 of the Employment Equity Act as employees.

\subsection{Promotion of Equality and Prevention of Unfair Discrimination Act}

The Promotion of Equality and Prevention of Unfair Discrimination Act 45 imposes a clear and unequivocal duty on the state to give special consideration to the rights of persons with disabilities. This legislation prevents and prohibits unfair discrimination by providing for procedures and substantive requirements for the determination of unfair discrimination to be made. The impairment of human dignity; the position of the complainant in society and whether he or she suffers from patterns of disadvantage or belongs to a group which so suffers; and whether or not the respondent has taken steps to accommodate diversity, are pivotal aspects in discrimination cases. ${ }^{46}$

The Promotion of Equality and Prevention of Discrimination Act was introduced in order to comply with section 9(4) of the Constitution which places a duty on the state to pass national legislation to prevent or prohibit unfair discrimination and to promote the achievement of equality. This Act ${ }^{47}$ is intended to give substance to the constitutional commitment to equality by providing for a legal mechanism with which to confront, address and remedy the past and present forms of incidental, as well as institutionalised or structural, unfair discrimination and inequality. ${ }^{48}$

According to section $1\left(\right.$ viii) ${ }^{49}$, discrimination whether directly or indirectly is prohibited if it has a negative impact of disadvantaging or withholding benefits, opportunities or advantages from any person on one or more of the prohibited grounds. Prohibited grounds refer to "race, gender, sex, pregnancy, marital status, ethnic, or social origin, colour, sexual orientation, age, disability, religion, conscience, belief, culture, language and birth". These listed grounds are similar to those listed in terms of section 9 of the Constitution of South Africa.

The person alleging discrimination in terms of the above section must prove that it was based on any of the listed grounds and as a result he or she has been denied some opportunities or benefits. There is a difference in terms of the scope of application between the Employment Equity Act and the Promotion of Equality and Prevention of Unfair Discrimination Act since the Employment Equity Act covers only employees defined in terms of section 1, certain categories of workers are excluded e.g. independent contractors and South African national defence force. Those who are excluded in terms of section 1 of Employment Equity Act can seek recourse or protection from the Promotion of Equality and Prevention of Unfair Discrimination Act if they encounter any discrimination.

In terms of section 2(c) ${ }^{50}$, the Act states that one of its objectives is to provide for measurers to facilitate the eradication of unfair discrimination, hate speech and harassment, particularly on the grounds of race, gender and disability. It is clear that in terms of the PEPUDA discrimination whether directly and indirectly is prohibited in terms of section 2; measures must be implemented to outlaw discrimination in respect of people with disabilities.

Unfair discrimination on the ground of disability is prohibited in terms of section 9 of PEPUDA, which reads as follows: "Subject to section 6, no person may unfairly discriminate against any person on the ground of disability including denying or removing from any person who has a disability, any supporting or enabling facility necessary for their functioning in society, and failing to eliminate obstacles that unfairly limit or restrict persons with disabilities from enjoying equal opportunities or failing to take steps to reasonably accommodate the needs of such.

The Promotion of Equality and Prevention of Unfair Discrimination Act encourages employers to remove any

\footnotetext{
${ }^{44}$ supra.

${ }^{45}$ Act 4 of 2000. hereafter referred to as the Equality Legislation.

${ }^{46}$ Olivier et al Social Security- A Legal Analysis (2003) 323.

47 Promotion of Equality and Prevention of Unfair Discrimination Act 4 of 2000.

${ }^{48}$ Albetyn C et al Introduction to Promotion of Equality and Prevention of Unfair Discrimination Act (2001) 3.

49 Promotion of Equality and Prevention of Unfair Discrimination Act 4 of 2000.

50 Supra.
} 
obstacle that may result in the inequality and discrimination of the employee based on disability. Such employees must not be denied access to facilities that will enable them to function and their needs must be reasonably accommodated. In terms of section 9 of PEPUDA, failure to eliminate obstacles that unfairly limit or restrict persons with disabilities from enjoying equal opportunities amounts to unfair discrimination. This Act closed a gap in section 1 of the Employment Equity Act, which covered a certain category of employees only. However it is not clear in terms of this Act how people with disabilities should be accommodated and it does not impose an obligation on employers to reasonably accommodate the needs of these people.

Both the Employment Equity Act and the Promotion of Equality and Prevention of Unfair Discrimination Act prohibit unfair discrimination at the workplace, and the Employment Equity Act advocates for equal opportunities of the designated groups, which include implementing measurers to reasonably accommodate people with disabilities at the employment place. The problem is that both Acts do not provide clear guidelines as to how people with disabilities should be reasonably accommodated and this gives the employers all the powers to determine how they should accommodate them. These Acts also do not stipulate clearly as to whether there are any strict measures or qualify penalty for employers who fail to accommodate people with disabilities.

The courts have made it clear that when dealing with the topical issue of disability or incapacity, it is important for employers to comply with existing legislations, inter alia, that alternatives must be considered. Failure to accommodate an employee on ground of disability amounts automatically to unfair dismissal. There have been some inconsistencies in dealing with the issue of affirmative action thus forcing some courts to declare that even in the absence of affirmative action policy, employers are still obliged to implement employment equity plan while other judges have held that employment equity plan cannot be implemented in the absence of affirmative action policy. Even though the policies and legislation that we have in place are in line with international standards, effective implementation remains a challenge.

\section{Discussion and Conclusion}

In South Africa, one can safely submit that relevant labour laws and policies have been passed, which clearly protect the rights of people with disabilities. The Labour Relations Act was passed to govern the relationship between employer and employee, and also to ensure that there is no unfair discrimination and unfair labour practices at various employment places. Subsequently the Employment Equity Act also was introduced in a quest to eliminate employment barriers and to call for positive measures in order to reasonably accommodate people with disabilities at the workplace.

A Code of Good Practice that basically supplements the Employment Equity Act, the Integrated National Disability Strategy and the Technical Guidelines on the Employment of People with Disabilities, which provide some guidelines on how people with disabilities should be reasonably accommodated must be hailed as a positive step towards ensuring that the labour rights of people with disabilities are protected and upheld. In view of the above laws and policies, it is clear that the government has played an important role by taking a significant statutory measures aimed at protecting the rights of all the employees including people with disabilities and integrating them into the labour markets.

The Employment Equity Act is indeed welcomed by people with disabilities as progressive on the basis that it attempts to address the disadvantages faced by people with disability in the workplace. This Act does not prohibit failure to reasonably accommodate people with disabilities as a form of discrimination; it views it as a positive measure that must be included by employers to attain equal opportunities. Employers are obliged to reasonably accommodate the needs of people with disabilities. The accommodation might vary from one person to another. If an employer fails to accommodate the needs of people with disabilities or raises an excuse that accommodation is very expensive, then measures to remedy the situation must be put in place.

Possible factors that can be taken into account to determine whether a specific accommodation can be expected to be made include financial costs involved, the size of the employer, possible safety risks and the benefit acquired by the employee. The Employment Equity Act has been of great assistance to people with disabilities, as it promotes their rights at the workplace and prohibits discrimination of any nature. It also provides for equal opportunities and lastly it obliges employers to design measurer to accommodate the needs of people with disabilities.

The need to reasonably accommodate people with disabilities in the labour market remains a challenge if not a problem to the employers. It is incumbent on employers to comply with the above stated legislation and be guided by the government in order to reasonably accommodate people with disabilities at the workplace whether as job applicants or employees. The constitution enjoins equal protection and benefit of the law to everyone including people with disabilities. In the spirit of this section, employers should be encouraged by the state to give effect to the equality clause.

The importance of this study is that it has been able to provide remedies to the pitfalls faced by employers and 
employees who do not understand the principle of reasonable accommodation and to enable people with disabilities to access the labour market. Furthermore, this study has been limited to the Public sector in order to ascertain whether the government is in compliance with its labour laws.

The practical implications are that if the labour laws and policies are not correctly implemented and the courts too, do not intervene to provide clear guidelines on this topical of reasonable accommodation of people with disabilities, the South African Labour Market will continue to exclude people with disabilities, primarily because they enjoy no protection of the law. In conclusion, little has been done to recruit and reasonably accommodate people with disabilities.

We also recommend that the government, employers in all sectors, NGO's and Human rights activists should increase awareness among able-bodied employees to accommodate employees with disabilities. This will certainly eliminate unfair discrimination and promote their participation in the workplace. Equally important, a policy on special damages should be adopted whereby any aggrieved employee with disability whose constitutional right to equality has been infringed on or who suffer any unfair discrimination can approach the constitutional court and claim damages. This policy should be separated from the process that normally ensues when an employee has suffered any form of discrimination on the listed grounds at the workplace.

Labour laws must be strictly implemented and monitored by officials of the department of labour at all levels. Employees should further be encouraged to blow the whistle against non-compliance with the labour laws with necessary protection. This is premised on the fact that on a daily basis the employers breach the laws knowing that there are some flaws within the monitoring, enforcement and inspectorate of labour department. Subsequently employees suffer without any recourse.

In conclusion, the article discussed the legal and constitutional framework of reasonable accommodation of people with disabilities in the labour market. The protection and accommodation of people with disabilities in the labour market is of great importance to South Africa where past work-place practices have often discriminated against large group of workers. There is now a renewed sensitivity to fairness at the workplace and some employers sometimes run afoul of the regulations just simply because they do not know better. This work sets out to surface the salient debates and make appropriate recommendations to good practice in this regard.

\section{References}

Text

Albertyn C Introduction of Equality and Prevention of Unfair Discrimination 2001 Witwatersrand University Press Johannesburg De Waal J \& Curie I The Bill of Rights Handbook 2005 Juta Cape Town Dupper $O$ et al Essential Employment Discrimination law 1'st ed 26 (2004 Juta Cape Town). Du Toit D et al Labour Relations Law: A Comprehensive 2006 LexisNexis Durban Olivier M P et al Social Security: A Legal Analysis 2003 Butterworths Durban

\section{Dissertation \& Thesis}

Truter L, Doctoral Thesis-Disability Discrimination (Unpublished) Submitted at University of Johannesburg.

\section{Internet Sources \& Articles}

Isaak W The Prohibition of Unfair Discrimination in the Workplace accessible at www.equality.org.za Mc Clain C V Article on Government and legislation in South Africa: A Contemporary Overview accessible at www.disabilityworld.org

\section{Policies}

White Paper on Integrated National Disability Strategy (November 1997).

\section{Legislation}

Employment Equity Act 55 of 1998

Labour Relations Act 66 of 1995

The Constitution of the Republic of South Africa, 1996.

Promotion of Equality and Prevention of Unfair Discrimination Act, 4 of 2000 


\section{Cases}

BDM Knitting Mills (Pty) Ltd v Sactwu 20017 BLLR SA 705 LAC

Brink v Kitshof 19964 SA 197 CC

Burger v Governing Body of Newcastle Senior Primary 20052 BALR 175 CCMA

Coetzer \& Another v Min of Safety and Security 20033 SA 368 LC

Dudley v City of Cape Town 20048 BCLR 805 CC

Dupper $O$ et al Essential Employment Discrimination Law 2004 Juta Cape Town

Elvey International (Pty) Ltd 19955 SA 108 IC

George v Liberty Life 1996 BLLR 985 IC

Harksen v Lane 1998 (1) SA 300 CC

Harmse v City of Cape Town 20036 BLLR 357 LC

Henn v Eskom 19966 SA 747 IC

Hoffman v SAA 200221 SA 2357 IC

Lagadien v University of Cape Town 20011 SA 76 LAC

Leornard Dingler Employee Representative Council \& Others v Leornard (Pty) Ltd \& Others 199819 SA 295

Liberty Life Association v George 1996 BLLR 985 IC

Mambula v AECI Explosives Ltd 19955 SA 62 IC

Nehawu obo Lucas v Department of Health: Western Cape 200425 ILJ 2091 BCA

Nehawu v SA Institute for Medical Research 19972 SA 146 IC

Numsa v Atlantis Diesel Engines 1993 ILJ 642 LAC

Promotion of Equality and Prevention of Unfair Discrimination Act, 4 of 2000

SACTWU \& Others v Afrox Ltd 199910 BLLR SA 1005 LAC

Tshaka v Vodacom (Pty) Ltd 200526 ILJ 568 CCMA

Walters v Transitional Local Council of Port Elizabeth 2001 SA 98 LC 